\title{
A Review of the Research on School Accident
}

\author{
Mei Liu \\ Kunming College \\ Kunming, China
}

\begin{abstract}
At present, the research on school accidents has been very deep, but some theoretical issues related to school accidents are still arguing and there is no clear conclusion. This paper intends to make a brief review of important theoretical issues in school accidents, hoping to bring some inspiration to later researchers.
\end{abstract}

Keywords—school accident; legal relationship; imputation principle; compensation

\section{INTRODUCTION}

In recent years, the number of articles about school accidents has increased greatly, which has become a hot topic in the theoretical field and sparked heated discussions among experts and scholars on the responsibility of school accidents. The author searches the Chinese journal full-text database in the name of school accidents and a total of 143 articles published in various journals from 2000 to 2017, 42 dissertations, and 9 monographs on school accidents were collected. The content analysis is expanded below.

\section{OVERVIEW OF RESEARCH ON SCHOOL ACCIDENT}

From the perspective of vertical development, the study of school accidents has the following characteristics: First, the research has gone through three historical stages. The first stage is before the introduction of the "Methods for Handling Student Injury Accidents" in 2002, and the second stage is from 2002 to 2010 when The Tort Liability Law was promulgated, and the third stage is after 2010. Secondly, the content of the research is getting deeper and deeper. The articles before 2002 mainly made superficial discussion on the meaning, characteristics, causes and prevention of school accidents. In 2002, accompanied by the introduction of the "Methods for Handling Student Injury Accidents", the research on school accidents has gradually been deepened; after the implementation of the Tort Liability Law in 2010, the problem of school responsibility in school accidents has become clearer and clearer. Therefore, in the past five years, the research has become deeper, and began to discuss the imputation principle for school accidents and make comparative study on relevant laws of other foreign countries (America, Canada, South Korea, Japan, etc.).

From the perspective of horizontal development, research on school accident in recent years has shown the following two characteristics: (1) diversification of research perspectives. First of all, it is reflected in different disciplines. Taking the dissertation as an example, there are about 20 dissertations in law majors, and about 20 dissertations in education and related majors. In addition, most scholars made theoretical research from the disciplinary perspective of law or educational law, accounting for about 95\%; a few scholars have taken a different approach and studied from the perspectives of economics, management, and sociology, accounting for about $5 \%$. Secondly, in the research object, most scholars talk about school accidents in general; some scholars focus on school accidents in primary and secondary schools (or underage students); some scholars study school accidents in colleges or rural areas; some scholars discuss the responsibility problems of injury accidents in school sports activities; some scholars study the legal and practical issues of accidents in foreign schools. Finally, it is reflected in the research content. Most scholars mainly discuss the legal responsibility and compensation of school accidents, especially academic dissertation, most of which analyze the problem of imputation of school accidents from the perspective of jurisprudence, accounting for about $80 \%$; in addition, some scholars focus on the types, causes, countermeasures, and legal remedies of school accidents; some scholars aim to explore the legal relationship between schools and students in school accidents. (2) The comprehensiveness of the research methods. Regarding the study of school accidents, the researchers have different perspectives and different research fields, so research methods have the characteristics of pluralism and comprehensive intersections. The articles of comprehensive theoretical research account for about $95 \%$. These articles reflect the diversification of research methods in the research process, including comparative research methods, case analysis methods, historical research methods, and experience summary methods, etc.; the practice survey article only accounts for about $5 \%$, which are mainly smallscale questionnaire research. Taking the dissertation as an example, there are only two papers on investigation and research. (Respectively, the dissertation of Ding Xueyi from Suzhou University, "Investigation and Analysis of the Status of Sports Injury Accidents in Wuxi Middle Schools", and Fang Wu's Dissertation in Central China Normal University "The Impact of School Sports Injury Accidents on Physical Activities in Primary and Secondary Schools in Jiangxia District of Wuhan City and the Countermeasures")

\section{THE MAIN RESUlTS OF SCHOOL ACCIDENT RESEARCH IN THE PAST TWO DECADES}

\section{A. The Concept and Nature of School Accidents}

There are many names about casualties in school, such as "campus accidents", "student injury accidents", "student 
casualties" and "school accidents". The first three definitions are not accurate enough in terms of connotation and extension, so we advocate the concept of "school accidents". [1]

Regarding the concept of "school accidents", the current academic circles have not yet formed a unified understanding, and the understanding in society is not the same. There is no concept of school accidents in the existing legal texts in China. Only the "student injury accident" as stipulated in Article 2 of the "Measures for the Handling of Student Injury Accidents" issued by the Ministry of Education on June 25, 2002 refers to the accidents that cause personal injury of the students in the school in the educational activities implemented in school or the offcampus activities organized by the school, as well as the school buildings, venues, other educational facilities and living facilities that school have management responsibilities." In addition, most scholars define school accidents as: "The human casualty accident that occurred during the school's education and teaching management process." [2]A few scholars believe that "school accidents refer to personal injury accidents caused by negligent behavior in schools", and some scholars have defined the school accident as follows: "School accidents refer to student casualties caused by the activities close contact with school activities." [3]

Scholars have basically agreed on the following aspects: First, the spatial concept of school accidents, includes the off-campus activities and on-campus activities organized by schools; second, the concept of the time of school accidents, refers to the period when students receive school education and management, and the period during which students are enrolled in school; thirdly, the objective aspects of school accidents include both personal injury and fatal accident. The differences mainly lie in three aspects. First, regarding the subjective aspects of school accidents, some scholars believe that school accidents include the intention and negligence of the school, as well as the school's no-fault accidents; some scholars believe that the school should not include the intentional act of the school. For example: Professor Lao Kaisheng believes that "school accidents refers to the incidents that occur in schools and other educational institutions or occur in activities organized by schools and other educational institutions out of schools or other educational institutions, and result in the student's personal injury due to the fail in foreseeing because of the negligence of the school and the teacher, or the easy believe in avoidable nature after foresight."[4] Second, most people think that school accidents merely refer to student injury accidents; a few people think that school accidents should include all personal injury accidents. Third, regarding the scope of school accidents, some scholars believe that it includes colleges and universities; some scholars believe that school accidents only include juveniles such as kindergartens, primary school and middle school students.

\section{B. Types of School Accidents}

Regarding the type of school, based on different classification criteria, scholars probably have the following classifications.

- Classification based on the subjects of school accidents School accidents can generally be divided into four types: (1) accidents caused by school management, (2) accidents caused by the behavior of faculty and staff, (3) school accidents caused by students' own behavior or sake, and (4) school accidents caused by behaviors of third parties other than schools and students.

- Classification based on the school's responsibility (1) School direct liability accidents, (2) School indirect liability accidents, (3) School no-fault liability accidents, and (4) schools no-obligation accidents.

- Classification based on the cause of the accident Fang Yiquan (2002), Zhu Hongqi (2000), and Li Xiaoyan (2001) listed the types of school accidents in the following ways: (1) accidents caused by lax school management, (2) accidents caused by quality problems of school buildings (3) accidents caused by old and aging school facilities, (4) accidents caused by teachers' negligence and lack of responsibility, (5) accidents caused by teachers' corporal punishment or corporal punishment in disguised form for students, (6) school accidents caused by sports activities, (7) accidents caused by labor or sanitation, (8) poor professional ethics and poor conduct of teachers, , (9) special physique or illness of students, (10) strong self-esteem and poor psychological endurance, (11) students wrongful behavior, (12) other sudden factors, and so on.

\section{The Legal Relationship Between the School and the Students in the School Accident}

The legal relationship between schools and students in school accidents has always been a hot issue for scholars. Since the current laws do not clearly define the legal relationship between the school and the students, the scholars hold their own opinions and argue with each other. The opinions of the scholars are roughly as follows:

1) The transfer of guardianship or transfer of partial guardianship: This view is mainly based on the guardian relationship in the civil law. It is believed that once students (mainly referring to nonage students) enter the school, the parent's guardianship for the students is naturally transferred to the school, and the school is supposed to become the guardian for nonage student, so it should fulfill the duties of the guardian, and assumes the responsibility of the guardian. First of all, this theory cannot find a theoretical basis. According to Article 16 of the General Principles of the Civil Law of China, only parents, grandfathers, grandmothers, brothers and sisters, and other close relatives, friends, neighborhood committees, village committees, and civil affairs departments can become 
guardians of juveniles, and any other organization or individuals can be a guardian. The school is clearly not listed here. Second, the school can't practice the duty of guardianship for underage students in practice. The rights and obligations of guardians and the legal responsibilities arising from obligations are very complicated and complex. As a special state-run institution established by the state, the school's main responsibility is to organize education and teaching, so it is powerless and impossible to assume the duty of guardianship of all students.

2) Entrusted guardian relationship: This view holds that when a child is sent to school, it means that the parents entrusted the guardianship to the school, so that a principalagent relationship is formed between the school and the parents of the students. Scholar Tong Lihua believes that "the relationship between the school and the student is civil legal relation based on the relationship of guardianship agent. The parents of the students are guardians, the school is the guardian agent, and the students are the third party. The guardian entrusts the part of the guardianship duties that is suitable for the school to the school, and pays the school tuition, management fees and other various expenses; the school fulfills other management matters authorized by the guardian when mainly performing the responsible for education. The basis of the different types of school guardianship agents is different. The guardianship agent obtained by the public school is the designated agent, while that obtained by the private school is the principal-agent. [5]

3) Special power relations: In China, the relationship between schools and students is very similar to the relationship between public corporations and management objects in civil law countries, and therefore should belong to special power relations. This theory holds that schools have the right to exercise their own disciplinary powers for the purposes of education and management, without the need for specific legal basis. Schools have the right to order students, and students have a high degree of obedience. However, Chen Futing believes that "China's current education law has certain characteristics similar to special power relations in stipulating the relationship between schools and students in China. However, the ills of such definition of the relationship between schools and students are obvious. This special power relationship between the school and the students has caused many problems in the reform and development of the current school system, because in the current education reform, the power relationship between the government and the school has undergone many fundamental changes. After the process of power re-distribution, the school has gradually gained greater autonomy and determined the civil legal status of the school. In many cases, the school no longer appears as the executive power. However, the existence of special relationships creates serious inequalities between schools and students. Therefore, determining the relationship between the school and the student as a special power relationship is obviously contrary to the current trend of the reform of the education system." [6]

4) Contractual relationship: According to the representative muroi chi of Japan, under the existing public education system, education should be completely free from the role of power. [7]Regardless of public or private schools, students's studying at school is essentially like shopping in department stores, which belongs purely to the scope of autonomy of private law and its relationship is the contractual relationship in private law and civil law. If there is a dispute, it will be tried by ordinary courts."[6] This view holds that parents send their children to the school according to the provisions of the Compulsory Education Law, and the school accepts the students according to law. They are fulfilling their respective obligations. At the same time, there is a relationship between the two, which is a contractual relationship with specific rights and obligations. The contract theory equates the school with the enterprise, which provides education management services to the students, and the service fees for the students in the compulsory education stage will be paid by the government. The contract theory ignores the nature of the public power performed by the school's public functions, which will inevitably lead to the industrialization of education and is not in line with reality. Chen Futing believes that "the theory of denial does not completely negate the existence of contractual relations in the school field. In fact, in some cases, there is indeed a free trade in the market between the school and the student or their parents. Projects other than the national education standards implemented by the school, such as providing meals, boarding, logistics, and specialties cultivation and study instruction activities in leisure time, can be regarded as a service because these contents is not defined as a paid service in the nationally prescribed educational standards, so the relationship formed should be regarded as a contractual relationship based on free trade. However, this view should not be extended to promote the contractual relationship between the school and the students or their parents formed under certain conditions as a general relationship in the school field. "[9]

5) Educational legal relationship: Most scholars believe that the relationship between school and students is actually a educational legal relationship. This relationship is regulated and adjusted by educational laws and regulations, embodying the essential characteristics of education. In the legal relationship of education, it includes some factors of administrative legal relationship, some characteristics of civil legal relationship, and even criminal legal relationship. It is a new, independent and comprehensive legal relationship as well as a relationship between education, management, and protection.

The educational legal relationship between the school and the students is regulated and adjusted by the education laws and regulations promulgated by the state. The school and the students, as the independent legal relations subjects, 
enjoy rights and obligations according to the laws and regulations of education, especially stressing the protection of students' rights, and once the rights of students are violated, relief protection can be carried out through the necessary means, including judicial procedures. [10]

\section{The Imputation Principle of School Accidents}

The imputation principle is the basis and standard for investigating civil liability. According to the law, there are two ways to bear civil liability: one is tortious liability and the other is responsibility for breach of contract. School accidents belong to tortious liability. The imputation principle of school accidents has been discussed before the promulgation of the Tort Liability Law, but most of them are based on the analysis of legal principle and discussion of judicial practice cases. After the promulgation of the Tort Liability Law, there is legal basis for the imputation of school accidents. After summarizing the viewpoints of several scholars, there are roughly the following kinds of imputation principles:

1) The principle of liability for fault: This principle is recognized by almost everyone. Article 106, paragraph 2, of the General Principles of the Civil Law stipulates: "Citizens and legal persons shall bear civil liability for infringing on the collective property of the state and the property or person because of fault." Article 38 of the Tort Liability Law stipulates: If a person without civil capacity suffers personal injury during the study or life in a kindergarten, school or other educational institution, the kindergarten, school or other educational institution shall bear the responsibility, but those can prove they have fulfilled the responsibility for education or management do not need to bear responsibility. This legal norm stipulates that the basic imputation principle for school accidents is the principle of fault liability. According to this principle, if a school is at fault in a school accident, it should be liable for compensation; if the school is not at fault, it will not be liable for compensation. If it is partially faulty, it bear part of the responsibility or additional responsibility. Article 40 of the Tort Liability Law stipulates: If a person without civil capacity or a person with limited capacity for civil conduct is physically injured out of a kindergarten, school or other educational institution during the study or life of a kindergarten, school or other educational institution, the infringer shall bear the tort liability; if the kindergarten, school or other educational institution fails to fulfill its management duties, it shall bear corresponding supplementary responsibilities.

If the school need to bear the civil liability of infringement, it must meet four constitutive requirements: one is the fact of damage; the second is that school behavior (including acts and negative acts) is illegal; third, there is a causal relationship between the illegal acts and the facts of damage; fourth is that the doer is subjectively at fault. Whether their psychological state is intentional or negligent, they are legally responsible. When the principle of liability for fault is applied, the burden of proof is the injured party (student).

2) Fault presumed responsibility: The presumption of liability is a special case of fault liability. The principle of fault presumed responsibility refers to the legal system in which the perpetrator is presumed to be at fault and be responsible for the tort liability if the perpetrator fails to prove that he is not at fault after the violation has occurred. Article 39 of the Tort Liability Law stipulates: "If a person with limited capacity for civil conduct suffers personal injury during his or her studies or life in a school or other educational institution, the school or other educational institution bear the responsibility when they fail to fulfill the education or management duties." Different from the fault liability, the burden of proof for the presumption of liability is based on the special principle of "the defendant's evidence". This is because of fair consideration, because the person with limited capacity for civil conduct cannot correctly judge whether the behavior of the school is at fault or not out of the guardianship of the guardian, nor can they or it is difficult for them to present the factual basis of the fault in the school management process. This principle is applied from the perspective of more effective protection of the legitimate rights and interests of students. Article 7 of the "Several Provisions of the Supreme People's Court on Evidence in Civil Proceedings" stipulates: "When there is no specific provision in the law, according to these provisions and other judicial interpretations, the burden of proof cannot be determined, the people's courts may, based on the principle of fairness and good faith, determine the assumption burden of proof comprehensively by considering the factors such as the ability of burden of evidence of the party. However, some scholars oppose the principle of fault presumption. The reason is: "The school is a non-profit legal organization. There is no obvious imbalance in the economic power and the litigation status between the school and the victims of student injury accidents, so there is no need for school to provide special protection; in judicial practice, some courts have reflected that the biggest problem in dealing with student injury accidents lies in the difficulty of proof. Often, in the case that the facts of the case cannot be proved, it is necessary to presume that the school bears part of the responsibility; the application of the presumption of fault will improperly expand the responsibility of school. In order to be exempted from responsibility, the school will inevitably reduce all kinds of educational activities that may be responsible. This is not conducive to the school's normal education and teaching activities, and is not conducive to promoting quality education. "[11]

3) Equitable liability principle: The scholars who support the equitable liability principle are mainly based on the provisions in Article 132 of the General Rule of the Civil Law: "If the parties are not at fault for causing damage, the parties may share the civil liability according to the 
actual situation. "Therefore, the equitable liability principle is within the discretionary scope. "The law does not stipulate the application of the principle of nonfault, but applying the fault principle is obviously unfair. Therefore, from the perspective of balance of interests, the principle of liability for sharing damage between the two parties is the principle of fair liability. Therefore, fairness is the value concept of the principle of fair liability. The application of equitable liability principle is conducive to balancing the interests of the parties and achieving social justice. Therefore, it is reasonable to apply the equitable liability principle in juvenile student injury accidents. [12]

The reason for the opponents is that the equitable liability principle will infinitely magnify the legal responsibility of the school in school accidents, and once this principle is established, high compensation will bring huge economic pressure to the school as a non-profit business organization.

Some scholars also hold an intermediate opinion that the equitable liability principle can be used, but this principle cannot be abused in specific judicial practice. Therefore, the scope of application of the equitable liability principle should be limited. Fair liability is primarily applicable to student injuries that result from school failures in physical education classes and other activities organized at school. In students' free activities during classes and after the class, if the students are harmed when school has no faults, it will not bear legal responsibility." The substantial fairness and justice pursued and embodied by the principle of fair liability are not only in full compliance with the spirit of fairness as stipulated in Article 4 of the General Rules of the Civil Law, but also in line with the basic concept of the modern legal system that "where there is damage, there is relief". When defining the responsibilities of schools in school accidents, fairness responsibilities also have a moderately applicable space. " [13]

4) Principle of no-fault liability: In this principle, the views of scholars are the same. They all agree that the principle of no-fault liability is not applicable. From the logic of law, the application of principle of liability for fault and the principle of no-fault liability is contradictory. The legal basis is that the principle of no-fault liability is applied only when state organs have tort liability, product quality problems, highly dangerous operations, and polluted environment in China's "General Rules of Civil Law". The school is clearly not listed here.

\section{E. Liability Exemption Conditions of School Accident}

The exemption condition refers to the legal condition for the exemption of legal liability. The exemption conditions for civil liability stipulated in China's Civil Law generally include: executing official duties according to law; justifiable defense; emergency avoidance; victim's consent; self-help and victim's intention; third person's fault; force majeure and accident. Article 14 of the Measures of Handling Student Injury Accidents: "If the personal injury of students is caused by the personal behavior of the school teacher or other staff members unrelated to their duties or the illegal acts committed by students, teachers and other individuals on purpose, the victim is responsible according to the law.

In addition, some scholars have proposed to regard the assumption of risk as an independent defense, and have also gained some judgments in the judicial practice. The assumption of risk means that if the party "expressed the consent in the act or other means to expressly consent to accept the risk of harm, no compensation shall be claimed for the damage unless the consent violates the public interest or good customs and thus is invalid." "If the victim is fully aware of the danger of being victimized, but voluntarily chooses to participate in the act or activity, and according to his circumstances, he or she has the willing to accept the risk, the victim doesn't have right to claim compensation for the damage caused within the dangerous scope."[10] It means that if the student still chooses the risk behavior under the conditions of repeated shackles and warnings from the school and the teacher, resulting in casualties, and the school can prove that it has fulfilled its obligation of education and management, it does not bear legal responsibility.

\section{F. Relief Approach and Compensation for School Accidents}

Articles 15 to 22 of the "Measures of Handling Student Injury Accidents" provide the procedures for handling student injury accidents, which are broadly divided into notification, rescue, accident reporting, guidance and assistance, mediation, litigation and other procedures for education. It determines the methods, steps, time limits, and order that should be followed in dealing with student injury accidents for administrative agencies, schools, students, and parents to ensure that student injury accidents are handled fairly and reasonably. According to relevant laws, scholars believe that there are three ways to remedy school accidents: negotiation, adjustment, and litigation. [15] [16]

With regard to the issue of school accident compensation, scholars mainly analyze the following aspects: 1 . the scope of compensation. "According to the relevant provisions of the General Rules of the Civil Law: the scope of student personal injury compensation mainly includes four aspects of compensation: First is regular compensation, including medical expenses, nutrition fees, subsidies for lost labor, nursing fee, lodging fee and car fare. Second is disability compensation, including disability compensation, disability aids fee, and disability living allowances, etc.; third is the compensation for death, including funeral expenses, dependents living expenses, death compensation fees, and transportation expenses, accommodation fees and lost labor for relatives of victims to handle funeral matters; Fourth is mental injury solatium. 2. Compensation subjects. According to the responsibility of school accidents, there are (1) school compensation; (2) guardian compensation; (3) social compensation; (4) for mixed faults, responsibility should be shared by universities; (5) if all parties are not at fault, it should be compensated according to the equity principle. [10]3. Compensation funds. Articles 29 and 30 of the Measures of Handling Student Injury Accidents respectively stipulate that: "According to the agreement reached between the two parties, if the agreement formed through mediation or the effective judgment of the people's court that the school 
shall be responsible for the compensation, the school shall be responsible for raising; if school is unable to fully raise, it can be assisted by the school's competent authority or organizer. If the education administrative department or the school organizer of the people's government at or above the county level has conditions, it can, through various forms such as the establishment of a student injury compensation reserve, raise the compensation according to law." 4. Compensation system. Article 31 of the Measures of Handling Student Injury Accidents stipulates that "If the school has conditions, it shall participate in school liability insurance in accordance with the relevant provisions of the Insurance Law." Therefore, most scholars recommend the establishment of a student injury accident compensation system led by school liability insurance. For example, in the case of Shanghai, fund will be provided by the government or multiple parties to establish a unified mandatory school liability insurance system. Some scholars have proposed to establish the following three systems: "establishing a special compensation fund system for students' personal injury; establishing a student accident insurance system; establishing a school liability insurance system." "From the experience of foreign countries, they generally solve the problem of student injury accidents through the insurance system. For example, the governments of Canada, Germany and other countries have set up school liability insurance in the insurance system to transfer school education risks; Japan solves similar problems in the form of welfare. The Ministry of Education has led to establish a unified and special nonprofit school accident insurance organization, the 'School Health Association'. [16]

\section{G. Suggestions on the Legal Regulation of School Accidents}

In terms of legal regulation, the suggestions put forward by scholars can be summarized as follows. 1. It is recommended that the "Measures for Handling Student Injury Accidents" be promoted to law. 2. It is recommended to include the treatment of child injury accidents in kindergartens into the "Measures for Handling Student Injury Accidents". 3. It is suggested to simplify the method of dividing the liability for personal injury caused by student injury accidents. 4. It is recommended that the boarding school be assumed to take more responsibility through legislation. 5. The amending advice for The Tort Liability Law dealing with the amendments to Articles 38 and 39 of the provisions on school casualties in primary and secondary schools. [18]6. The responsibility of the school in the injury accidents of students of different ages.

In the end, the basic characteristics of school accident research in recent years are that from the reality of school accidents, the comparative study between domestic and foreign countries has been strengthened. Especially after the promulgation of the Tort Liability Law, the study of school accidents transferred from simple theoretical discussion to educational investigation and legal regulation. However, the author believes that the existing research has the following shortcomings: (1) more repetitive research; (2) lack of jurisprudential research in rational legal perspective; (3) empirical research such as investigation needs to be further strengthened.

\section{H. Several Issues That Should Be Addressed in the Future}

1) The legal definition of school accidents needs to be further determined: The connotation and extension of the existing school accidents are quite broad, which has led to people's misunderstandings in school accidents, campus accidents, student injury accidents, student casualties, and student accidents. Therefore, the title of current school accident is a very imprecise concept, so the definition of the legal meaning of school accidents must be redefined.

2) The legal relationship between schools, teachers and students needs to be further defined: For the legal remedies and compensation issues of student casualties result from the infringement of schools and teachers, there are differences and disputes in judicial practice. The fundamental reason is that there is divergence in understanding of the legal relationship between schools, teachers and students. Only when the status between these subjects and the legal relationship is determined can we guarantee the settlement of school accident disputes through legal judicial remedies and safeguard the legitimate rights and interests of students.

3) Education legislation needs to be further regulated: From the current system of education law in China, the education regulations issued by the Ministry of Education to local education authorities at all levels are various in names. In recent years, there have been more and more local administrative legislations on school accidents. The General Principles of Civil Law, the Law on the Protection of Minors, the Law on Education, the Regulations on the Prevention and Treatment of Personal Injury Accidents of Primary and Secondary School Students issued in Shanghai, Hangzhou and Beijing, the Measures for Handling Student Injury Accidents, and the Supreme People's Court Interpretation of Several Issues Concerning the Application of Law in Personal Damage Compensation Cases, and Tort Liability Law, etc. However, there is always a lack of legal norms with relatively consistent value standards, stability, and operability. Therefore, the author suggests that on the one hand, it is necessary to strengthen the legislation of the National People's Congress and to enact the "School Safety Law". On the other hand, it is suggested to regulate the administrative legislation of education.

\section{CONCLUSION}

The author believes that China's legislation on student accident liability is still not perfect from the perspective of current judicial practice. The existing laws and regulations and departmental regulations are too general, lacking of operability and controversial. The promulgation of the Tort Liability Law has enabled us to obtain relatively complete legislative support in the handling of this legal relationship. However, it is undeniable that there are still many disputes. Moreover, due to the characteristics of multiple accidents, 
unpredictability, massive damage and complexity, we should learn from the experience of other foreign developed countries and Taiwanese countries in establishing a system of student personal injury to improve China's relevant legal system.

\section{REFERENCES}

[1] Zhu Hongqi. On School Accidents and Their Legal Responsibilities [J]. Journal of Teaching and Management, 2000(1): 15.

[2] Liu Zongsheng. Analysis of the Legal Liability of School Accidents [J]. The Study on Legal System Modernization, 2003 (5): 415.

[3] Ouya kunyu. Responsibility Jurisprudence of School Accidents [M]. Beijing: Legal Culture Society, 2005: 18.

[4] Lao Kaisheng. Research on the injury accidents and responsibility of primary and middle school students[J]. Journal of Beijing Normal University, 2004(2): 50.

[5] Tong Lihua. Juvenile Jurisprudence [M]. Beijing: China Democracy and Legal Publishing House.2001: 150-152.

[6] Chen Futing. Study on the legal relationship between school and students and the responsibility of student injury accidents [D]. Jilin University, 2005: 10. 12.

[7] Zhou Zhiwen. Analysis of the legal status of public universities in China and its legal relationship with students [D]. Sichuan University, 2006:12.

[8] Sun Ping. Research on the legal relationship between schools and students [J]. Education and Vocation, 2007 (9): 34.

[9] Qian Wei. On the school's liability and legislative perfection in student injury accidents [D]. University of International Trade and Economics, 2006: 16.28.29.

[10] Li Wei. Study on the school responsibility of underage student injury accident [D]. Jilin University. 2004:38.

[11] Long Zhuhua. Several legal problems caused by school accidents to minor students [J]. Guangxi Social Sciences, 2006 (6): 61.

[12] Yang Lixin, Lv Chunchun. Infringement cases should be applied as a duty of exemption [N]. People's Court Daily, March 24, 2010.

[13] Zheng Ting. Clarifying rights and obligations to deal with school disputes according to law - students' accidental injury in school needs to be legislated [J]. Shanghai research in higher education, 1998(9): 33.

[14] Huang Qian. Research on school legal responsibility in campus infringement accident [D]. Jilin University of Finance and Economics, 2014:22.

[15] Zhou Ruoqi. On the civil legal responsibility of schools in the accidents of primary and secondary school campus [D]. Capital University of Economics and Business, 2012: 33 . 